\title{
A genetic perspective on the domestication continuum
}

\author{
Laurent A. F. Frantz1,2 and Greger Larson2
}

1 School of Biological and Chemical Sciences, Queen Mary University of London, London, UK 2 The Palaeogenomics \& Bio-Archaeology Research Network, Research Laboratory for Archaeology and History of Art, The University of Oxford, Oxford, UK.

\section{Introduction}

Beginning with dogs over 15,000 years ago, the domestication of plant and animals has played a key role in the development of modern societies. The importance of domestication for archeology, biology, and humanities, means that it has been studied extensively. Over the past decades, new conceptual models of animal domestication have emerged from the archeological literature that are trying to break away from anthropocentric view of domestication. These models describe domestication as a gradual process, but also question the ubiquity of human intent during the early stages of the process (Ervynck et al. 2001, Vigne 2011, Zeder 2011). Under this view, domestication is thought as continuous the process by which a species alter, voluntarily or involuntarily, the phenotype of an other and assumes a significant degree of influence over its care and reproduction (Zeder 2015). These models stand in stark contrast with the traditional views that involve intent and strong directed breeding from humans (Bökönyi 1989, Clutton-Brock 1992, Larson and Fuller 2014).

This view of domestication also refrains from generalising a process that might be highly species specific (Vigne 2011). This is done by broadly defining three pathways to domestication: commensal, prey and directed pathway, each with different varying degree of intent (Zeder 1982). Under the commensal pathway, for example, domestication is most diffuse and involve little intent while under the directed domestication is fully intentional with human directed breeding starting during early phases of domestication. In the latter model, humans apply a strong dichotomy between what is considered wild and domestic.

The striking morphological and behavioral changes associated with the process of domestication also makes it an excellent model to study evolution. Understanding the broad mechanisms that allow for fast evolution in domestic taxa is a central question in evolutionary biology. In contrast with species specific pathways to domestication advocated by some archeologists, biologists, however, are often more interested in drawing conclusions that are globally applicable to the process than species specific. For example, multiple studies have focused on understanding common biological features (e.g. developmental processes) underlying a general "domestication syndrome" in both plants (Sakuma et al. 2011, Allaby 2014) and animals (Wilkins et al. 2014, Sánchez-Villagra et al. 2016). This is an interesting contrast between an "archeological" and a "biological" views of domestication.

Genetics have been instrumental in studying biological aspects of domestication. For simplicity, however, genetic studies generally model domestication as a process involving strong bottlenecks (also called founder events), reproductive isolation between wild and domestic and strong artificial selection. These models provide a great framework for geneticists to address questions such as geographic origin, strength of selection and demography of domestication (Frantz et al. 2015). This view of domestication, however, implies strong control of the breeding of domestic species as well 
as strong artificial selection that also stand in contrast with the archaeological view of domestication as a more fluid process.

Armed with new DNA sequencing technologies, geneticists are now able to sequence and analyse large scale genetic information from both modern and archeological samples. These genomes provide an ever greater resolution to address fundamental questions about domestication, and in particular to test the veracity of recent theories. Here we first discuss how genetics can provide key information to test various models of domestication and then review the degree to which genetic evidence supports these models.

\section{Models of domestication and their expectations}

Conceptual models of domestication based on the idea of intent involve a combination of key characteristics 1) a founder effect (also called a bottleneck see Figure 1a) as only a few individuals are domesticated (Eyre-Walker et al. 1998, Doebley et al. 2006, Larson and Burger 2013) 2) strong artificial selection for traits that define domestic species (e.g. behaviour; Figure 1a) (Trut 1999, Trut et al. 2009) 3) reproductive isolation enforced between wild and domestic population to facilitate trait differentiation (e.g. keep animal tame; Figure 1c) (Marshall et al. 2014) 4) simpler genetic architecture of traits (Andersson 2013). While these characteristics provide a great framework for geneticists to study domestication, as key events (e.g. geographical origin and timeframe of domestication) they do occasionally contradict the expectations associated with the more diffuse models of domestication proffered by archeologists (Vigne 2011, Zeder 2011, Marshall et al. 2014).

The first and maybe most obvious difference between these models of domestication is the expected strength of bottlenecks. Figure $1 \mathrm{a}$ is a schematic of a model in which a wild population undergoes a "domestication" bottleneck as a result of a human-directed domestication. In this example, the wild population prior to domestication has two alleles (blue and red). After domestication, however, only the black remains, as the result of a founder effect (since the founding population possessed only the black allele). While drastic, this example highlights one major expectation of a directed model with human intent: a severe bottleneck resulting in a significant loss of genetic diversity. Bottlenecks can, as we will see later in this chapter, also result from directed breeding (for example during the formation of a specific breed) as highlighted in Figure $1 \mathrm{~b}$. In a more diffuse model, however, in which domestication proceeds unintentionally, the expectation is that a domestication bottleneck will be less severe (or even absent). This is because the process will happen somehow more "naturally" and thus more individuals will be involved in the founding of the domestic population and will have more chance to capture an equal number of black and white alleles.

Conscious selection by humans for specific traits is also expected to reduce genetic diversity. In our example in Figure 1a, the white allele could be represented by aggressive individuals. Strong "artificial" selection would be applied against these individual in a domestic population. On the other hand, if domestication proceeds unintentionally, selection is not expected to be as strong simply because individuals that are, for example, aggressive (or simply less tame) will not be directly selected against. The expectations of a directed model of domestication, as opposed to a more diffuse model with no intent, are rather similar to the one of severe/mild bottlenecks: differential level of genetic diversity (Figure 1a\&b). 
Another expectation of directed models of domestication is the maintenance of reproductive isolation (prevent breeding between wild and domestic population). As we show in Figure 1c, gene-flow (exchange of genetic material) between wild and domestic populations can increase genetic diversity. If conscious selection is applied on a domestic population people might have imposed strict reproductive isolation from wild populations. Preventing gene-flow from wild animals would provide a framework for faster selection of domestic traits (Frantz et al. 2015). On the other hand, without conscious selection, domestication proceeds similarly to parapatric speciation models which can (and often do) involve gene flow (Vigne 2011, Larson and Fuller 2014, Frantz et al. 2015). By taking advantage of modern DNA sequencing, geneticists are now able to generate the necessary data, including genomes from modern and archeological samples, to test these key expectations underlying intentional models of domestication.

\section{Domestication, genetic diversity, bottlenecks and breed formation}

Genetic studies of domestication often assume a domestication bottleneck in both plants (Zhu et al. 2007, Xu et al. 2011) and animals such as dogs (Freedman and Wayne 2017)(Frantz et al. 2016) (Lindblad-Toh et al. 2005), cattle (Bollongino et al. 2012) (Scheu et al. 2015) (Beja-Pereira et al. 2006)(MacLeod et al. 2013), goats (Gerbault et al. 2012), and rabbits (Carneiro et al. 2014). The idea of a domestication bottleneck is so embedded in the genetic literature that it is often taken as prior knowledge (Bollongino et al. 2012); (Scheu et al. 2015); (Gerbault et al. 2012). For at least some species, genetic data has supported the idea of a lower genetic diversity in domestic populations especially dogs (Marsden et al. 2016), cattle (Bollongino et al. 2012, MacLeod et al. 2013) and rabbits (Carneiro et al. 2014). Dogs are the most drastic example, especially as breed dogs are significantly more inbred than wolves (Frantz et al. 2016); (Marsden et al. 2016).

Interestingly, in dogs, most of genetic diversity is thought to have been lost during severe bottlenecks linked to breed formation (Wang et al. 2013, 2014) and therefore may not reflect processes that took place during domestication itself. Domestication may have induced a reduction of genetic variation of less than $20 \%$ (Wang et al. 2014). Recent breeding efforts in purebred dogs have thus resulted in more severe bottlenecks than domestication itself, as indicated by the higher level of genetic diversity observed in free living dogs (village dogs (Marsden et al. 2016). This more recent and drastic bottleneck, however, does not explain all differences between wolf and dogs, suggesting that a milder bottleneck took place during domestication (Marsden et al. 2016). The exact timing of this earlier bottleneck and therefore its association with domestication has yet to be tested with ancient DNA (see below).

While reduced genetic diversity is a clear pattern common to multiple domestic species it is not generally applicable to all domestic animals. Indeed, recent studies of pigs (Bosse et al. 2014, Frantz et al. 2015) bees (Wallberg et al. 2014), chickens (Rubin et al. 2010) and yaks (Qiu et al. 2015) found no reduction of genetic diversity in domestic populations, suggesting that no domestication bottlenecks has taken place in these species. Pigs and chickens, are thought to have been domesticated via a commensal pathway (Zeder 2011, Larson and Fuller 2014). Under this pathway, early stages of domestication are thought to be fully unintentional. The lack of a bottleneck in these species might reflect the specificity of this pathway. Multiple factors, however, complicate the interpretation the genetic diversity level in pigs, chickens and bees, especially their propensity to interbreed with wild stock (Eriksson et al. 2008, Wallberg et al. 2014, Frantz et al. 2015). Outbreeding with wild populations could indeed inflate genetic diversity as pictured in Figure $1 \mathrm{c}$. 
Another factor that complicates interpretation of these findings is the genetic diversity in wild populations. Indeed, most analyses inferring bottlenecks often rely on comparing genetic diversity with wild counterparts. This, however, can be problematic if wild populations have themselves undergone recent bottlenecks, or, in more dramatic cases have gone extinct as it is the case for aurochs. This is an issue for many species such as wolves (Freedman et al. 2014, Fan et al. 2015), wild boars (Bosse et al. 2012, Frantz et al. 2015) or wild horses (Jónsson et al. 2014, Schubert et al. 2014). Understanding the dynamics in wild populations is therefore key to characterize the severity of bottlenecks during domestication.

\section{Reproductive isolation}

Archeologists have suggested that interbreeding between wild and domestic forms may be an important feature of most domestication processes (Marshall et al. 2014). The consequences of interbreeding are numerous. Firstly, as mentioned above (and as shown in Figure 1c) gene flow can increase the level of genetic diversity in a population. Indeed, if gene flow from a wild population into a domestic population takes place after a (domestication) bottleneck, genetic diversity will be restored to some degree (depending on the number of wild individuals that contribute to the domestic population). Gene flow from wild stock can also affect the phenotypic evolution of a domestic species. This is because gene-flow can have homogenising effect - in other words, gene flow could prevent the domestic population from sustaining divergent phenotypes. By reducing gene flow it is therefore possible to accelerate the process of phenotypic differentiation (e.g. behavioural) between wild and domestic. Similarly, the establishment of barrier to gene flow is thought to be an important process during speciation, especially when differentiated, yet closely related species/subspecies occur in parapatric conditions (Feder et al. 2012).

The processes that reduce gene flow between differentiated populations also enforce reproductive isolation. The characteristics and types of reproductive isolation have been studied extensively in wild populations (Seehausen et al. 2014). Reproductive isolation can be classified roughly into three categories: extrinsic postzygotic / prezygotic and intrinsic (Seehausen et al. 2014). Two species are intrinsically isolated if they cannot reproduce due to intrinsic biological specificity or genetic incompatibility (e.g. difference in ploidy). On the other hand, two species might be partially isolated due to, for example, behavioural differences (extrinsic prezygotic isolation) or due the low fertility of their offspring (extrinsic postzygotic isolation). In general, while in many cases permeable, these barriers to gene flow are a key aspect of speciation as they are necessary for two species to maintain their different phenotype.

Just as in speciation, the maintenance of reproductive isolation is key for domestication (Price 2002). This is particularly true under a model in which domestication is intentional (Marshall et al. 2014). Under this scenario, reproductive isolation in domestic animals can be imposed by humans (in domestic populations, though this is not always the case) and by natural selection (in wild populations). These barriers to gene flow can be seen as an extrinsic prezygotic (domestic) and postzygotic (wild) and will assist in the maintenance of domestic traits. In domestic populations, humans can act as an extrinsic prezygotic isolation mechanism by preventing mating with wild individuals. In wild populations, however, mating is not necessarily prevented, but the fitness of a cross between wild and domestic offspring might be lower (due to relaxed selection in domestic population). This can be seen as postzygotic isolation. 
Maintaining reproductive isolation between wild and domestic populations, however, varies dramatically among species. Many plant species have and continue to interbreed with their wild relative, including banana and plantain (Andersson and de Vicente 2010), barley (Baum et al. 1992), cassava (Duputié et al. 2007), maize (da Fonseca et al. 2015), pearl millet (Miura and Terauchi 2005), potato (Scurrah et al. 2008), sorgho (see Garine this volume) and apples (Cornille et al. 2012). Levels of outcrossing are, however, highly variable among species (Andersson and de Vicente 2010). Many species have also formed partial intrinsic reproductive barrier with their wild progenitor, often as a result of changes in level of ploidy such as in cotton and sweet potato (Andersson and de Vicente 2010). A recent review, however, suggested that only $38 \%$ of all cultivated plants are partially or fully reproductively isolated from their wild ancestor (Dempewolf et al. 2012). Outcrossing between wild and domestic also seem common in domestic animals, including cattle (Park et al. 2015), pigs (Frantz et al. 2015), dromedary camels (Almathen et al. 2016), cats (Ottoni et al. 2017) and horses (Lippold et al. 2011).

Armed with whole genome sequences, geneticists are now able to evaluate the degree of gene flow between wild and domestic populations in greater detail. Taken together, these studies have demonstrated how the rate of genetic exchange varies among species. In pigs and dogs, for example, levels of genetic exchange are dramatically different. Besides widespread gene-flow from dogs into wolves populations (see Lescureux in this volume; (Fan et al. 2015)) and a few examples of deliberate crossing between wolf and dogs (e.g. Sarloos breed; (Morris 2008)), global dog populations form a genetically homogeneous cluster with little evidence for outbreeding with wolves (Freedman et al. 2014, Fan et al. 2015, Frantz et al. 2016, Wang et al. 2016). The lack of outbreeding with wolves is not solely a recent phenomenon as demonstrated by ancient DNA studies demonstrating that Neolithic dogs from Europe ( $>5,000$ years old) also show little evidence of interbreeding with wild canids (Thalmann et al. 2013, Frantz et al. 2016, Botigué et al. 2017). Pigs, on the other hand, show a drastically different pattern with high level of outcrossing between wild and domestic populations (Frantz et al. 2015). While it is clear that outcrossing has taken place within the last few hundred years (since formation of some breeds), this phenomenon is likely to have taken place for thousands of years as suggested by ancient DNA analysis (Larson et al. 2007). Interestingly, the direction of interbreeding between wild and domestic forms seem to be reversed in pigs and canids. In canids, interbreeding takes place most often from domestic dogs into wolves populations (see Lescureux in this volume) and from wild boars into domestic pigs (Frantz et al. 2015).

The ubiquity of outcrossing raises the question of how the highly derived phenotypic characteristics associated with domestication are maintained in the face of gene flow. One possibility is that recurrent strong artificial selection for domestic traits (e.g. behaviour) reduced the effects of gene flow which would otherwise prevent the domestic traits from increasing in frequency (Larson and Fuller 2014, MacHugh et al. 2017). Speciation theory suggests that this should leave footprints of selection in region of the genome that control for the phenotypic differences between two species (Turner et al. 2005). These regions have coined "Islands of speciation". In pigs, while the domestic/wild status of an individual is virtually impossible to determine within most of the genome, some regions show a clear pattern of genetic homogeneity among domestic pigs (Frantz et al. 2015). One of these regions, for example, is linked to the higher number of vertebrae found in domestic pigs. This provides an interesting similarity between the process of domestication and speciation, suggesting the potential existence of "Islands of domestication" in the genomes of domestic species (Frantz et al. 2015). 
It is thus clear that outcrossing must have pervasive effects on phenotypes that differentiate domestic and wild populations (e.g. behaviour). It is interesting to note that such mechanisms may be responsible for the limited amount of gene-flow from wolf to dogs suggested above. Gene flow, however, may also be beneficial in some cases, for example for traits that are highly variable among breeds (e.g. coat colour). As such, gene-flow may provide novel genetic variation in domestic populations and enhance the potential for breeders to diversify traits. In addition, gene flow from wild populations may also provide the means for domestic populations to adapt to novel environments, such as in high altitude dogs (Miao et al. 2017, vonHoldt et al. 2017) or by augmenting immune capability (Vilà et al. 2005) or by providing novel coat colours (Fang et al. 2009, Linderholm et al. 2016).

While our understanding of outcrossing between wild and domestic populations is still rudimentary, its clear association with domestication suggests some interesting parallels with the process of speciation. As for speciation, gene-flow between domestic and wild population appears to be variable among species, suggesting that domestication is highly species specific. Gene flow is also suggestive that the modern dichotomy between wild and domestic populations may be something relatively recent suggesting that intent might not be an important feature of domestication (Larson and Fuller 2014).

\section{Artificial and relaxed selection}

As for bottlenecks and reproductive isolation, strong and deliberate artificial selection is also often associated with intentional domestication as a means to select for traits that differentiate domestic populations from their wild progenitors. Strong artificial selection can affect overall genetic diversity during bottlenecks (Figure 1a) and leaves specific footprints in the genome (localised reduction of genetic diversity, also know as a selective sweep). These can be detected and used to identify genes under selection (Vitti et al. 2013). The application of these methods, combined with recent sequencing technologies, have revealed many regions under selection in the genome of domestic plants including rice, tomato and maize (Lai et al. 2010, Xu et al. 2011, Lin et al. 2014) and animals including chickens, rabbits, dogs, and horses (Rubin et al. 2010, 2012, Axelsson et al. 2013, Carneiro et al. 2014, Frantz et al. 2015, Librado et al. 2017). Genetic mapping (also known as linkage mapping) has also been employed to characterise the genetic architecture of traits that differentiate within domestic populations (Schoenebeck et al. 2012, Andersson 2013)). Although less common, this method has also been applied to compare wild and domestic populations (Andersson-Eklund et al. 1998).

Scans for the footprints of selection are often conducted by comparing genomes derived from modern populations (Girdland Flink et al. 2014). While selection can often be reasonably well identified, these methods do not possess little power to infer the time at which selection occurred (Peter et al. 2012). This is problematic because comparing modern genomes does not provide the means to disentangle selection that happened recently (e.g. breed improvement) from selection that took place during the early phases of domestication (Larson and Fuller 2014), especially given that selection during early phases are not necessarily expected to lead to strong morphological differentiation (Zohary et al. 1998, Vigne 2008).

The recent generation of ancient DNA (aDNA) sequences is starting to provide clues regarding the importance of artificial selection in the past, including the type of traits that were and were not selected early on. In chickens, for example, two recent aDNA studies (Girdland Flink et al. 2014, 
Loog et al. 2017) demonstrated that the selection for an allele involved in seasonal reproduction that differentiate modern chickens and Red Jungle fowls (Rubin et al. 2010), only began driving the allele to fixation about 1,000 years ago. Similarly, alleles linked to better starch digestion in dogs, a phenotype that strongly differentiate them from wolves (Axelsson et al. 2013) only arouse $>7,000$ years after they were domesticated (Ollivier et al. 2016).

Artificial selection is not the only type of selection expected during domestication. By moving plants and animals from natural to different environments (e.g. introduction of wild boars to Cyprus), especially to anthropogenic niches (Zeder 2016), humans may have relaxed natural selection constraints on domestic species. Relaxed selection is an interesting proxy to study domestication from a genetic perspective due to some relatively well understood and expected outcomes (MacHugh et al. 2017). Relaxation of selective constraints predicts that more deleterious mutations (mutations that have a negative impact on an individual) would segregate within domestic than wild populations. These deleterious mutations are also expected to be more common in populations that have undergone recent bottlenecks. Studying relaxed selection therefore provides an ideal proxy to test the importance that human directly played during early stages of domestication because deleterious alleles would be expected to increase gradually as animals or plants are moved from natural to anthropogenic ecosystems and/or because of bottlenecks.

Studies of horses and dogs have shown that these species carry more deleterious mutations as expected under the relaxed selection hypothesis (Marsden et al. 2016, Librado et al. 2017). This, however, does not generally apply to all domesticated species (Moray et al. 2014). In addition, issues such already low level of deleterious mutations in wild progenitors (e.g. Przewalski's horses) can also complicate inference of relaxed selection. Nevertheless, a recent study of ancient horse genomes demonstrated clear patterns that can be associated with relaxed selection by showing that modern horses have accumulated more deleterious mutations in their genome than early domestic populations (Librado et al. 2017).

Relaxed selection, as measured via deleterious load can also be difficult to disentangle from other mechanisms. For example, the frequency of deleterious mutations can increase together with other other alleles that are under positive selection (increasing in frequency) - a process called genetic hitchhiking. Lastly, populations that are not at an equilibrium (e.g. that underwent recent expansion or bottleneck) will have skewed frequency of neutral variants (Brandvain and Wright 2016) which can affect methods that compare the frequency of neutral and deleterious variation in a population. Future research is needed to investigate how to over these challenges.

\section{The rise of ancient genomes}

Using modern genetic data alone, domestication can appear to be an abrupt process during which a species has been drastically altered relative to its wild progenitor. Modern data, however, only provides a snapshot of what archaeologists showed to be a long and continuous process. In many cases, modern genomes can only inform us about the recent past (e.g. selection scan and genes linked to improvement). Recent technological advances in DNA sequencing and methods to recover DNA from bones provide the means to solve these issues. Through sequencing of ancient genomes of domestic and wild species, it is possible to obtain direct measurements of genetic diversity, relaxed/artificial selection and gene flow in ancient populations. By comparing these measurements through time, it is possible to assess how gradual the process of domestication has been. 
Besides a few examples, ancient DNA studies have yet to tackle fundamental questions about the process of domestication. This can be mostly attributed to the prohibitive cost of associated with generating a high quality nuclear genome from ancient DNA. Genome sequencing effort of ancient horses (Schubert et al. 2014, Librado et al. 2017), dogs (Frantz et al. 2016), and maize (da Fonseca et al. 2015) have, nevertheless, generated sufficient information to draw some interesting conclusions about the process of domestication in these species by demonstrating, for example, a sharp reduction of genetic diversity in both modern dogs and horses and a sharp increase of genetic load in the latter.

\section{Conclusions}

Even the most recent studies have only begun to scratch the surface of the enormous potential of genomes as a window into domestication. An interesting trend is nevertheless emerging: domestication is highly species specific. Bottlenecks, reproductive isolation, and strong selection are by no means ubiquitous features but rather linked to species (and even region) specific pathways of domestication. The process of domestication in animals such as dogs, pigs, chickens, bees and many others plant and animal species affected their genomes in dramatically different ways. This probably reflects specific human-animal/plant relationships during domestication as has been suggested by numerous archaeologists. Like speciation, domestication comes in many forms, parapatric or allopatric, with intrinsic and/or extrinsic reproductive isolations, strong or diffuse selection. Interestingly, this highly taxon specific depiction of domestication that is emerging from field such as genetics and archeology provide a scientific basis for the sociologists that question the usefulness of imposing a general wild/domestic dichotomy in wildlife conservation (see Lescureux in this volume).

Genome-wide information, especially ancient genomes, offers an incredible tool to study domestication. For example, studying relaxed selection through time, but especially during early stages, will provide critical evidence for the importance that selection and intent played in specific domestication processes but also for our understanding of fundamental evolutionary questions (Brandvain and Wright 2016). Understanding past genetic diversity in domestic taxon will not only allow us to understand the importance that genetic variability played during domestication, but also to understand the future and potential sustainability of our farming systems.

\section{References}

Allaby, R.G., 2014. Domestication Syndrome in Plants. In: C. Smith, ed. Encyclopedia of Global Archaeology. Springer New York, 2182-2184.

Almathen, F., Charruau, P., Mohandesan, E., Mwacharo, J.M., Orozco-terWengel, P., Pitt, D., Abdussamad, A.M., Uerpmann, M., Uerpmann, H.-P., De Cupere, B., Magee, P., Alnaqeeb, M.A., Salim, B., Raziq, A., Dessie, T., Abdelhadi, O.M., Banabazi, M.H., Al-Eknah, M., Walzer, C., Faye, B., Hofreiter, M., Peters, J., Hanotte, O., and Burger, P.A., 2016. Ancient and modern DNA reveal dynamics of domestication and cross-continental dispersal of the dromedary. Proceedings of the National Academy of Sciences of the United States of America, 113 (24), 6707-6712.

Andersson-Eklund, L., Marklund, L., Lundström, K., Haley, C.S., Andersson, K., Hansson, I., Moller, M., and Andersson, L., 1998. Mapping quantitative trait loci for carcass and meat quality traits in a wild boar x Large White intercross. Journal of animal science, 76 (3), 694700.

Andersson, L., 2013. Molecular consequences of animal breeding. Current opinion in genetics \& development, 23 (3), 295-301.

Andersson, M.S. and de Vicente, M.C., 2010. Gene Flow Between Crops and Their Wild Relatives. 
JHU Press.

Axelsson, E., Ratnakumar, A., Arendt, M.-L., Maqbool, K., Webster, M.T., Perloski, M., Liberg, O., Arnemo, J.M., Hedhammar, A., and Lindblad-Toh, K., 2013. The genomic signature of dog domestication reveals adaptation to a starch-rich diet. Nature, 495 (7441), 360-364.

Baum, M., Lagudah, E.S., and Appels, R., 1992. Wide Crosses in Cereals. Annual review of plant physiology and plant molecular biology, 43 (1), 117-143.

Beja-Pereira, A., Caramelli, D., Lalueza-Fox, C., Vernesi, C., Ferrand, N., Casoli, A., Goyache, F., Royo, L.J., Conti, S., Lari, M., Martini, A., Ouragh, L., Magid, A., Atash, A., Zsolnai, A., Boscato, P., Triantaphylidis, C., Ploumi, K., Sineo, L., Mallegni, F., Taberlet, P., Erhardt, G., Sampietro, L., Bertranpetit, J., Barbujani, G., Luikart, G., and Bertorelle, G., 2006. The origin of European cattle: evidence from modern and ancient DNA. Proceedings of the National Academy of Sciences of the United States of America, 103 (21), 8113-8118.

Bökönyi, S., 1989. Definitions of animal domestication. The Walking Larder. Patterns of Domestication, Pastoralism, and Predation, 24-27.

Bollongino, R., Burger, J., Powell, A., Mashkour, M., Vigne, J.-D., and Thomas, M.G., 2012. Modern taurine cattle descended from small number of near-eastern founders. Molecular biology and evolution, 29 (9), 2101-2104.

Bosse, M., Megens, H.-J., Madsen, O., Frantz, L.A.F., Paudel, Y., Crooijmans, R.P.M.A., and Groenen, M.A.M., 2014. Untangling the hybrid nature of modern pig genomes: a mosaic derived from biogeographically distinct and highly divergent Sus scrofa populations. Molecular ecology.

Bosse, M., Megens, H.-J., Madsen, O., Paudel, Y., Frantz, L.A.F., Schook, L.B., Crooijmans, R.P.M.A., and Groenen, M.A.M., 2012. Regions of homozygosity in the porcine genome: consequence of demography and the recombination landscape. PLoS genetics, 8 (11), e1003100.

Botigué, L.R., Song, S., Scheu, A., Gopalan, S., Pendleton, A.L., Oetjens, M., Taravella, A.M., Seregély, T., Zeeb-Lanz, A., Arbogast, R.-M., Bobo, D., Daly, K., Unterländer, M., Burger, J., Kidd, J.M., and Veeramah, K.R., 2017. Ancient European dog genomes reveal continuity since the Early Neolithic. Nature communications, 8, ncomms 16082.

Brandvain, Y. and Wright, S.I., 2016. The Limits of Natural Selection in a Nonequilibrium World. Trends in genetics: TIG, 32 (4), 201-210.

Carneiro, M., Rubin, C.-J., Di Palma, F., Albert, F.W., Alfoldi, J., Barrio, a. M., Pielberg, G., Rafati, N., Sayyab, S., Turner-Maier, J., Younis, S., Afonso, S., Aken, B., Alves, J.M., Barrell, D., Bolet, G., Boucher, S., Burbano, H. a., Campos, R., Chang, J.L., Duranthon, V., Fontanesi, L., Garreau, H., Heiman, D., Johnson, J., Mage, R.G., Peng, Z., Queney, G., Rogel-Gaillard, C., Ruffier, M., Searle, S., Villafuerte, R., Xiong, A., Young, S., Forsberg-Nilsson, K., Good, J.M., Lander, E.S., Ferrand, N., Lindblad-Toh, K., and Andersson, L., 2014. Rabbit genome analysis reveals a polygenic basis for phenotypic change during domestication. Science, 345 (6200), 1074-1079.

Clutton-Brock, J., 1992. The process of domestication. Mammal review, 22 (2), 79-85.

Cornille, A., Gladieux, P., Smulders, M.J.M., Roldán-Ruiz, I., Laurens, F., Le Cam, B., Nersesyan, A., Clavel, J., Olonova, M., Feugey, L., Gabrielyan, I., Zhang, X.-G., Tenaillon, M.I., and Giraud, T., 2012. New insight into the history of domesticated apple: secondary contribution of the European wild apple to the genome of cultivated varieties. PLoS genetics, 8 (5), e1002703.

Dempewolf, H., Hodgins, K.A., Rummell, S.E., Ellstrand, N.C., and Rieseberg, L.H., 2012. Reproductive isolation during domestication. The Plant cell, 24 (7), 2710-2717.

Doebley, J.F., Gaut, B.S., and Smith, B.D., 2006. The molecular genetics of crop domestication. Cell.

Duputié, A., David, P., Debain, C., and McKey, D., 2007. Natural hybridization between a clonally propagated crop, cassava (Manihot esculenta Crantz) and a wild relative in French Guiana. Molecular ecology, 16 (14), 3025-3038.

Eriksson, J., Larson, G., Gunnarsson, U., Bed'hom, B., Tixier-Boichard, M., Strömstedt, L., Wright, D., Jungerius, A., Vereijken, A., Randi, E., Jensen, P., and Andersson, L., 2008. Identification of the yellow skin gene reveals a hybrid origin of the domestic chicken. PLoS genetics, 4 (2), 
e1000010.

Ervynck, A., Hongo, H., Dobney, K., and Meadow, R., 2001. Born Free ? New Evidence for the Status of Sus scrofa at Neolithic Çayönü Tepesi (Southeastern Anatolia, Turkey). Paléorient, 27 (2), 47-73.

Eyre-Walker, A., Gaut, R.L., Hilton, H., Feldman, D.L., and Gaut, B.S., 1998. Investigation of the bottleneck leading to the domestication of maize. Proceedings of the National Academy of Sciences of the United States of America, 95 (8), 4441-4446.

Fang, M., Larson, G., Ribeiro, H.S., Li, N., and Andersson, L., 2009. Contrasting mode of evolution at a coat color locus in wild and domestic pigs. PLoS genetics, 5 (1), e1000341.

Fan, Z., Silva, P., Gronau, I., Wang, S., Armero, A.S., Schweizer, R.M., Ramirez, O., Pollinger, J., Galaverni, M., Ortega Del-Vecchyo, D., Du, L., Zhang, W., Zhang, Z., Xing, J., Vilá, C., Marques-Bonet, T., Godinho, R., Yue, B., and Wayne, R.K., 2015. Worldwide patterns of genomic variation and admixture in gray wolves. Genome research, gr.197517.115-.

Feder, J.L., Egan, S.P., and Nosil, P., 2012. The genomics of speciation-with-gene-flow. Trends in genetics: TIG, 28 (7), 342-350.

da Fonseca, R.R., Smith, B.D., Wales, N., Cappellini, E., Skoglund, P., Fumagalli, M., Samaniego, J.A., Carøe, C., Ávila-Arcos, M.C., Hufnagel, D.E., Korneliussen, T.S., Vieira, F.G., Jakobsson, M., Arriaza, B., Willerslev, E., Nielsen, R., Hufford, M.B., Albrechtsen, A., RossIbarra, J., and Gilbert, M.T.P., 2015. The origin and evolution of maize in the Southwestern United States. Nature plants, 1, 14003.

Frantz, L.A.F., Mullin, V.E., Pionnier-Capitan, M., Lebrasseur, O., Ollivier, M., Perri, A., Linderholm, A., Mattiangeli, V., Teasdale, M.D., Dimopoulos, E.A., Tresset, A., Duffraisse, M., McCormick, F., Bartosiewicz, L., Gál, E., Nyerges, É.A., Sablin, M.V., Bréhard, S., Mashkour, M., Bălăşescu, A., Gillet, B., Hughes, S., Chassaing, O., Hitte, C., Vigne, J.-D., Dobney, K., Hänni, C., Bradley, D.G., and Larson, G., 2016. Genomic and archaeological evidence suggest a dual origin of domestic dogs. Science, 352 (6290), 1228-1231.

Frantz, L.A.F., Schraiber, J.G., Madsen, O., Megens, H.-J., Cagan, A., Bosse, M., Paudel, Y., Crooijmans, R.P.M.A., Larson, G., and Groenen, M.A.M., 2015. Evidence of long-term gene flow and selection during domestication from analyses of Eurasian wild and domestic pig genomes. Nature genetics, 47 (10), 1141-1148.

Freedman, A.H., Gronau, I., Schweizer, R.M., Ortega-Del Vecchyo, D., Han, E., Silva, P.M., Galaverni, M., Fan, Z., Marx, P., Lorente-Galdos, B., Beale, H., Ramirez, O., Hormozdiari, F., Alkan, C., Vilà, C., Squire, K., Geffen, E., Kusak, J., Boyko, A.R., Parker, H.G., Lee, C., Tadigotla, V., Siepel, A., Bustamante, C.D., Harkins, T.T., Nelson, S.F., Ostrander, E.A., Marques-Bonet, T., Wayne, R.K., and Novembre, J., 2014. Genome sequencing highlights the dynamic early history of dogs. PLoS genetics, 10 (1), e1004016.

Freedman, A.H. and Wayne, R.K., 2017. Deciphering the Origin of Dogs: From Fossils to Genomes. Annual review of animal biosciences, 5, 281-307.

Gerbault, P., Powell, A., and Thomas, M.G., 2012. Evaluating demographic models for goat domestication using mtDNA sequences. Anthropozoologica, 47 (2), 64-76.

Girdland Flink, L., Allen, R., Barnett, R., Malmström, H., Peters, J., Eriksson, J., Andersson, L., Dobney, K., and Larson, G., 2014. Establishing the validity of domestication genes using DNA from ancient chickens. Proceedings of the National Academy of Sciences of the United States of America, 111 (17), 6184-6189.

Jónsson, H., Schubert, M., Seguin-Orlando, A., Ginolhac, A., Petersen, L., Fumagalli, M., Albrechtsen, A., Petersen, B., Korneliussen, T.S., Vilstrup, J.T., Lear, T., Myka, J.L., Lundquist, J., Miller, D.C., Alfarhan, A.H., Alquraishi, S.A., Al-Rasheid, K.A.S., Stagegaard, J., Strauss, G., Bertelsen, M.F., Sicheritz-Ponten, T., Antczak, D.F., Bailey, E., Nielsen, R., Willerslev, E., and Orlando, L., 2014. Speciation with gene flow in equids despite extensive chromosomal plasticity. Proceedings of the National Academy of Sciences of the United States of America, 111 (52), 18655-18660.

Lai, J., Li, R., Xu, X., Jin, W., Xu, M., Zhao, H., Xiang, Z., Song, W., Ying, K., Zhang, M., Jiao, Y., Ni, P., Zhang, J., Li, D., Guo, X., Ye, K., Jian, M., Wang, B., Zheng, H., Liang, H., Zhang, X., Wang, S., Chen, S., Li, J., Fu, Y., Springer, N.M., Yang, H., Wang, J., Dai, J., Schnable, P.S., and Wang, J., 2010. Genome-wide patterns of genetic variation among elite maize inbred 
lines. Nature genetics, 42 (11), 1027-1030.

Larson, G., Albarella, U., Dobney, K., Rowley-Conwy, P., Schibler, J., Tresset, A., Vigne, J.-D., Edwards, C.J., Schlumbaum, A., Dinu, A., Balaçsescu, A., Dolman, G., Tagliacozzo, A., Manaseryan, N., Miracle, P., Van Wijngaarden-Bakker, L., Masseti, M., Bradley, D.G., and Cooper, A., 2007. Ancient DNA, pig domestication, and the spread of the Neolithic into Europe. Proceedings of the National Academy of Sciences of the United States of America, 104 (39), 15276-15281.

Larson, G. and Burger, J., 2013. A population genetics view of animal domestication. Trends in genetics: TIG, 29 (4), 197-205.

Larson, G. and Fuller, D.Q., 2014. The Evolution of Animal Domestication. Annual review of ecology, evolution, and systematics, 45 (1), 115-136.

Librado, P., Gamba, C., Gaunitz, C., Der Sarkissian, C., Pruvost, M., Albrechtsen, A., Fages, A., Khan, N., Schubert, M., Jagannathan, V., Serres-Armero, A., Kuderna, L.F.K., Povolotskaya, I.S., Seguin-Orlando, A., Lepetz, S., Neuditschko, M., Thèves, C., Alquraishi, S., Alfarhan, A.H., Al-Rasheid, K., Rieder, S., Samashev, Z., Francfort, H.-P., Benecke, N., Hofreiter, M., Ludwig, A., Keyser, C., Marques-Bonet, T., Ludes, B., Crubézy, E., Leeb, T., Willerslev, E., and Orlando, L., 2017. Ancient genomic changes associated with domestication of the horse. Science, 356 (6336), 442-445.

Lindblad-Toh, K., Wade, C.M., Mikkelsen, T.S., Karlsson, E.K., Jaffe, D.B., Kamal, M., Clamp, M., Chang, J.L., Kulbokas, E.J., Zody, M.C., Mauceli, E., Xie, X., Breen, M., Wayne, R.K., Ostrander, E.A., Ponting, C.P., Galibert, F., Smith, D.R., DeJong, P.J., Kirkness, E., Alvarez, P., Biagi, T., Brockman, W., Butler, J., Chin, C.-W., Cook, A., Cuff, J., Daly, M.J., DeCaprio, D., Gnerre, S., Grabherr, M., Kellis, M., Kleber, M., Bardeleben, C., Goodstadt, L., Heger, A., Hitte, C., Kim, L., Koepfli, K.-P., Parker, H.G., Pollinger, J.P., Searle, S.M.J., Sutter, N.B., Thomas, R., Webber, C., Baldwin, J., Abebe, A., Abouelleil, A., Aftuck, L., Ait-Zahra, M., Aldredge, T., Allen, N., An, P., Anderson, S., Antoine, C., Arachchi, H., Aslam, A., Ayotte, L., Bachantsang, P., Barry, A., Bayul, T., Benamara, M., Berlin, A., Bessette, D., Blitshteyn, B., Bloom, T., Blye, J., Boguslavskiy, L., Bonnet, C., Boukhgalter, B., Brown, A., Cahill, P., Calixte, N., Camarata, J., Cheshatsang, Y., Chu, J., Citroen, M., Collymore, A., Cooke, P., Dawoe, T., Daza, R., Decktor, K., DeGray, S., Dhargay, N., Dooley, K.K., Dooley, K.K., Dorje, P., Dorjee, K., Dorris, L., Duffey, N., Dupes, A., Egbiremolen, O., Elong, R., Falk, J., Farina, A., Faro, S., Ferguson, D., Ferreira, P., Fisher, S., FitzGerald, M., Foley, K., Foley, C., Franke, A., Friedrich, D., Gage, D., Garber, M., Gearin, G., Giannoukos, G., Goode, T., Goyette, A., Graham, J., Grandbois, E., Gyaltsen, K., Hafez, N., Hagopian, D., Hagos, B., Hall, J., Healy, C., Hegarty, R., Honan, T., Horn, A., Houde, N., Hughes, L., Hunnicutt, L., Husby, M., Jester, B., Jones, C., Kamat, A., Kanga, B., Kells, C., Khazanovich, D., Kieu, A.C., Kisner, P., Kumar, M., Lance, K., Landers, T., Lara, M., Lee, W., Leger, J.-P., Lennon, N., Leuper, L., LeVine, S., Liu, J., Liu, X., Lokyitsang, Y., Lokyitsang, T., Lui, A., Macdonald, J., Major, J., Marabella, R., Maru, K., Matthews, C., McDonough, S., Mehta, T., Meldrim, J., Melnikov, A., Meneus, L., Mihalev, A., Mihova, T., Miller, K., Mittelman, R., Mlenga, V., Mulrain, L., Munson, G., Navidi, A., Naylor, J., Nguyen, T.T., Nguyen, N., Nguyen, C., Nguyen, T.T., Nicol, R., Norbu, N., Norbu, C., Novod, N., Nyima, T., Olandt, P., O’Neill, B., O’Neill, K., Osman, S., Oyono, L., Patti, C., Perrin, D., Phunkhang, P., Pierre, F., Priest, M., Rachupka, A., Raghuraman, S., Rameau, R., Ray, V., Raymond, C., Rege, F., Rise, C., Rogers, J., Rogov, P., Sahalie, J., Settipalli, S., Sharpe, T., Shea, T., Sheehan, M., Sherpa, N., Shi, J., Shih, D., Sloan, J., Smith, C., Sparrow, T., Stalker, J., Stange-Thomann, N., Stavropoulos, S., Stone, C., Stone, S., Sykes, S., Tchuinga, P., Tenzing, P., Tesfaye, S., Thoulutsang, D., Thoulutsang, Y., Topham, K., Topping, I., Tsamla, T., Vassiliev, H., Venkataraman, V., Vo, A., Wangchuk, T., Wangdi, T., Weiand, M., Wilkinson, J., Wilson, A., Yadav, S., Yang, S., Yang, X., Young, G., Yu, Q., Zainoun, J., Zembek, L., Zimmer, A., and Lander, E.S., 2005. Genome sequence, comparative analysis and haplotype structure of the domestic dog. Nature, 438 (7069), 803819.

Linderholm, A., Spencer, D., Battista, V., Frantz, L., Barnett, R., Fleischer, R.C., James, H.F., Duffy, D., Sparks, J.P., Clements, D.R., Andersson, L., Dobney, K., Leonard, J.A., and Larson, G., 2016. A novel MC1R allele for black coat colour reveals the Polynesian ancestry and 
hybridization patterns of Hawaiian feral pigs. Royal Society Open Science, 3 (9).

Lin, T., Zhu, G., Zhang, J., Xu, X., Yu, Q., Zheng, Z., and Zhang, Z., 2014. Genomic analyses provide insights into the history of tomato breeding. Nature.

Lippold, S., Knapp, M., Kuznetsova, T., Leonard, J.A., Benecke, N., Ludwig, A., Rasmussen, M., Cooper, A., Weinstock, J., Willerslev, E., Shapiro, B., and Hofreiter, M., 2011. Discovery of lost diversity of paternal horse lineages using ancient DNA. Nature communications, 2, 450.

Loog, L., Thomas, M.G., Barnett, R., Allen, R., Sykes, N., Paxinos, P.D., Lebrasseur, O., Dobney, K., Peters, J., Manica, A., Larson, G., and Eriksson, A., 2017. Inferring allele frequency trajectories from ancient DNA indicates that selection on a chicken gene coincided with changes in medieval husbandry practices. Molecular biology and evolution.

MacHugh, D.E., Larson, G., and Orlando, L., 2017. Taming the Past: Ancient DNA and the Study of Animal Domestication. Annual review of animal biosciences, 5, 329-351.

MacLeod, I.M., Larkin, D.M., Lewin, H.A., Hayes, B.J., and Goddard, M.E., 2013. Inferring demography from runs of homozygosity in whole-genome sequence, with correction for sequence errors. Molecular biology and evolution, 30 (9), 2209-2223.

Marsden, C.D., Ortega-Del Vecchyo, D., O’Brien, D.P., Taylor, J.F., Ramirez, O., Vilà, C., Marques-Bonet, T., Schnabel, R.D., Wayne, R.K., and Lohmueller, K.E., 2016. Bottlenecks and selective sweeps during domestication have increased deleterious genetic variation in dogs. Proceedings of the National Academy of Sciences, 113 (1), 152-157.

Marshall, F.B., Dobney, K., Denham, T., and Capriles, J.M., 2014. Evaluating the roles of directed breeding and gene flow in animal domestication. Proceedings of the National Academy of Sciences of the United States of America, 111 (17), 6153-6158.

Miao, B., Wang, Z., and Li, Y., 2017. Genomic Analysis Reveals Hypoxia Adaptation in the Tibetan Mastiff by Introgression of the Gray Wolf from the Tibetan Plateau. Molecular biology and evolution, 34 (3), 734-743.

Miura, R. and Terauchi, R., 2005. Genetic control of weediness traits and the maintenance of sympatric crop-weed polymorphism in pearl millet (Pennisetum glaucum). Molecular ecology, 14 (4), 1251-1261.

Moray, C., Lanfear, R., and Bromham, L., 2014. Domestication and the mitochondrial genome: comparing patterns and rates of molecular evolution in domesticated mammals and birds and their wild relatives. Genome biology and evolution, 6 (1), 161-169.

Morris, D., 2008. Dogs: The Ultimate Dictionary of Over 1,000 Dog Breeds. Trafalgar Square.

Ollivier, M., Tresset, A., Bastian, F., Lagoutte, L., Axelsson, E., Arendt, M.-L., Bălăşescu, A., Marshour, M., Sablin, M.V., Salanova, L., Vigne, J.-D., Hitte, C., and Hänni, C., 2016. Amy2B copy number variation reveals starch diet adaptations in ancient European dogs. Royal Society open science, 3 (11), 160449.

Ottoni, C., Van Neer, W., De Cupere, B., Daligault, J., Guimaraes, S., Peters, J., Spassov, N., Prendergast, M.E., Boivin, N., Morales-Muñiz, A., Bălăşescu, A., Becker, C., Benecke, N., Boroneant, A., Buitenhuis, H., Chahoud, J., Crowther, A., Llorente, L., Manaseryan, N., Monchot, H., Onar, V., Osypińska, M., Putelat, O., Quintana Morales, E.M., Studer, J., Wierer, U., Decorte, R., Grange, T., and Geigl, E.-M., 2017. The palaeogenetics of cat dispersal in the ancient world. Nature Ecology \& Evolution, 1 (7), s41559-017-0139.

Park, S.D.E., Magee, D.A., McGettigan, P.A., Teasdale, M.D., Edwards, C.J., Lohan, A.J., Murphy, A., Braud, M., Donoghue, M.T., Liu, Y., Chamberlain, A.T., Rue-Albrecht, K., Schroeder, S., Spillane, C., Tai, S., Bradley, D.G., Sonstegard, T.S., Loftus, B.J., and MacHugh, D.E., 2015. Genome sequencing of the extinct Eurasian wild aurochs, Bos primigenius, illuminates the phylogeography and evolution of cattle. Genome biology, 16 (1), 234.

Peter, B.M., Huerta-Sanchez, E., and Nielsen, R., 2012. Distinguishing between selective sweeps from standing variation and from a de novo mutation. PLoS genetics, 8 (10), e1003011.

Price, E.O., 2002. Animal Domestication and Behavior. New York: CABI Publishing.

Qiu, Q., Wang, L., Wang, K., Yang, Y., Ma, T., Wang, Z., Zhang, X., Ni, Z., Hou, F., Long, R., Abbott, R., Lenstra, J., and Liu, J., 2015. Yak whole-genome resequencing reveals domestication signatures and prehistoric population expansions. Nature communications, 6 , 10283.

Rubin, C.-J., Megens, H.-J., Martinez Barrio, A., Maqbool, K., Sayyab, S., Schwochow, D., Wang, 
C., Carlborg, Ö., Jern, P., Jørgensen, C.B., Archibald, A.L., Fredholm, M., Groenen, M.A.M., and Andersson, L., 2012. Strong signatures of selection in the domestic pig genome.

Proceedings of the National Academy of Sciences of the United States of America, 109 (48), 19529-19536.

Rubin, C.-J., Zody, M.C., Eriksson, J., Meadows, J.R.S., Sherwood, E., Besnier, F., Webster, M.T., Jiang, L., Ingman, M., Sharpe, T., Ka, S., Hallbo, F., Jensen, P., Siegel, P., Lindblad-toh, K., Carlborg, O., Bed, B., and Andersson, L., 2010. Whole-genome resequencing reveals loci under selection during chicken domestication.

Sakuma, S., Salomon, B., and Komatsuda, T., 2011. The domestication syndrome genes responsible for the major changes in plant form in the Triticeae crops. Plant \& cell physiology, 52 (5), 738-749.

Sánchez-Villagra, M.R., Geiger, M., and Schneider, R.A., 2016. The taming of the neural crest: a developmental perspective on the origins of morphological covariation in domesticated mammals. Royal Society open science, 3 (6), 160107.

Scheu, A., Powell, A., Bollongino, R., Vigne, J.-D., Tresset, A., Çakırlar, C., Benecke, N., and Burger, J., 2015. The genetic prehistory of domesticated cattle from their origin to the spread across Europe. BMC genetics, 16, 54.

Schoenebeck, J.J., Hutchinson, S.A., Byers, A., Beale, H.C., Carrington, B., Faden, D.L., Rimbault, M., Decker, B., Kidd, J.M., Sood, R., and Others, 2012. Variation of BMP3 contributes to dog breed skull diversity. PLoS genetics, 8 (8), e1002849.

Schubert, M., Jónsson, H., Chang, D., Der Sarkissian, C., Ermini, L., Ginolhac, A., Albrechtsen, A., Dupanloup, I., Foucal, A., Petersen, B., Fumagalli, M., Raghavan, M., Seguin-Orlando, A., Korneliussen, T.S., Velazquez, A.M.V., Stenderup, J., Hoover, C.A., Rubin, C.-J., Alfarhan, A.H., Alquraishi, S.A., Al-Rasheid, K.A.S., MacHugh, D.E., Kalbfleisch, T., MacLeod, J.N., Rubin, E.M., Sicheritz-Ponten, T., Andersson, L., Hofreiter, M., Marques-Bonet, T., Gilbert, M.T.P., Nielsen, R., Excoffier, L., Willerslev, E., Shapiro, B., and Orlando, L., 2014. Prehistoric genomes reveal the genetic foundation and cost of horse domestication. Proceedings of the National Academy of Sciences, 111 (52), E5661-E5669.

Scurrah, M., Celis-Gamboa, C., Chumbiauca, S., Salas, A., and Visser, R.G.F., 2008.

Hybridization between wild and cultivated potato species in the Peruvian Andes and biosafety implications for deployment of GM potatoes. Euphytica/ Netherlands journal of plant breeding, 164 (3), 881-892.

Seehausen, O., Butlin, R.K., Keller, I., Wagner, C.E., Boughman, J.W., Hohenlohe, P.A., Peichel, C.L., Saetre, G.-P., Bank, C., Brännström, A., Brelsford, A., Clarkson, C.S., Eroukhmanoff, F., Feder, J.L., Fischer, M.C., Foote, A.D., Franchini, P., Jiggins, C.D., Jones, F.C., Lindholm, A.K., Lucek, K., Maan, M.E., Marques, D.A., Martin, S.H., Matthews, B., Meier, J.I., Möst, M., Nachman, M.W., Nonaka, E., Rennison, D.J., Schwarzer, J., Watson, E.T., Westram, A.M., and Widmer, A., 2014. Genomics and the origin of species. Nature reviews. Genetics, 15 (3), 176-192.

Thalmann, O., Shapiro, B., Cui, P., Schuenemann, V.J., Sawyer, S.K., Greenfield, D.L., Germonpré, M.B., Sablin, M.V., López-Giráldez, F., Domingo-Roura, X., Napierala, H., Uerpmann, H.-P., Loponte, D.M., Acosta, A. a., Giemsch, L., Schmitz, R.W., Worthington, B., Buikstra, J.E., Druzhkova, A., Graphodatsky, a. S., Ovodov, N.D., Wahlberg, N., Freedman, a. H., Schweizer, R.M., Koepfli, K.-P., Leonard, J. a., Meyer, M., Krause, J., Pääbo, S., Green, R.E., and Wayne, R.K., 2013. Complete mitochondrial genomes of ancient canids suggest a European origin of domestic dogs. Science , 342 (6160), 871-874.

Trut, L., 1999. Early Canid Domestication: The Farm-Fox Experiment Foxes bred for tamability in a 40-year experiment exhibit remarkable transformations that suggest an interplay between behavioral genetics and development. American scientist, 87 (2), 160-169.

Trut, L., Oskina, I., and Kharlamova, A., 2009. Animal evolution during domestication: the domesticated fox as a model. BioEssays: news and reviews in molecular, cellular and developmental biology, 31 (3), 349-360.

Turner, T.L., Hahn, M.W., and Nuzhdin, S.V., 2005. Genomic Islands of Speciation in Anopheles gambiae. PLoS biology, 3 (9), e285.

Vigne, J.-D., 2008. Zooarchaeological Aspects of the Neolithic Diet Transition in the Near East and 
Europe, and Their Putative Relationships with the Neolithic Demographic Transition. In: The Neolithic Demographic Transition and its Consequences. Springer, Dordrecht, 179-205.

Vigne, J.-D., 2011. The origins of animal domestication and husbandry: a major change in the history of humanity and the biosphere. Comptes rendus biologies, 334 (3), 171-181.

Vilà, C., Seddon, J., and Ellegren, H., 2005. Genes of domestic mammals augmented by backcrossing with wild ancestors. Trends in genetics: TIG, 21 (4), 214-218.

Vitti, J.J., Grossman, S.R., and Sabeti, P.C., 2013. Detecting natural selection in genomic data. Annual review of genetics, 47, 97-120.

vonHoldt, B., Fan, Z., Ortega-Del Vecchyo, D., and Wayne, R.K., 2017. EPAS1 variants in high altitude Tibetan wolves were selectively introgressed into highland dogs. PeerJ, 5, e3522.

Wallberg, A., Han, F., Wellhagen, G., Dahle, B., Kawata, M., Haddad, N., Simões, Z.L.P., Allsopp, M.H., Kandemir, I., De la Rúa, P., Pirk, C.W., and Webster, M.T., 2014. A worldwide survey of genome sequence variation provides insight into the evolutionary history of the honeybee Apis mellifera. Nature genetics, 46 (10), 1081-1088.

Wang, G.-D., Xie, H.-B., Peng, M.-S., Irwin, D., and Zhang, Y.-P., 2014. Domestication genomics: evidence from animals. Annual review of animal biosciences, 2, 65-84.

Wang, G.-D., Zhai, W., Yang, H.-C., Fan, R.-X., Cao, X., Zhong, L., Wang, L., Liu, F., Wu, H., Cheng, L.-G., Poyarkov, A.D., Poyarkov, N.A., JR, Tang, S.-S., Zhao, W.-M., Gao, Y., Lv, X.M., Irwin, D.M., Savolainen, P., Wu, C.-I., and Zhang, Y.-P., 2013. The genomics of selection in dogs and the parallel evolution between dogs and humans. Nature communications, 4 , 1860.

Wang, G.-D., Zhai, W., Yang, H.-C., Wang, L., Zhong, L., Liu, Y.-H., Fan, R.-X., Yin, T.-T., Zhu, C.L., Poyarkov, A.D., Irwin, D.M., Hytonen, M.K., Lohi, H., Wu, C.-I., Savolainen, P., and Zhang, Y.-P., 2016. Out of southern East Asia: the natural history of domestic dogs across the world. Cell Res.

Wilkins, A.S., Wrangham, R.W., and Tecumseh Fitch, W., 2014. The 'Domestication Syndrome' in Mammals: A Unified Explanation Based on Neural Crest Cell Behavior and Genetics. Genetics, 197 (3), 795-808.

Xu, X., Liu, X., Ge, S., Jensen, J.D., Hu, F., Li, X., Dong, Y., Gutenkunst, R.N., Fang, L., Huang, L., Li, J., He, W., Zhang, G., Zheng, X., Zhang, F., Li, Y., Yu, C., Kristiansen, K., Zhang, X., Wang, J., Wright, M., McCouch, S., Nielsen, R., Wang, J., and Wang, W., 2011.

Resequencing 50 accessions of cultivated and wild rice yields markers for identifying agronomically important genes. Nature biotechnology, 30 (1), 105-111.

Zeder, M.A., 1982. The domestication of animals. Reviews in Anthropology, 9 (4), 321-327.

Zeder, M.A., 2011. Pathways to animal domestication. In: A. Damania and P. Gepts, eds. Harlan II: Biodiversity in Agriculture: Domestication, Evolution and Sustainability. Davis: Univ California Press, 227-229.

Zeder, M.A., 2015. Core questions in domestication research. Proceedings of the National Academy of Sciences of the United States of America, 112 (11), 3191-3198.

Zeder, M.A., 2016. Domestication as a model system for niche construction theory. Evolutionary ecology, 30 (2), 325-348.

Zhu, Q., Zheng, X., Luo, J., Gaut, B.S., and Ge, S., 2007. Multilocus analysis of nucleotide variation of Oryza sativa and its wild relatives: severe bottleneck during domestication of rice. Molecular biology and evolution, 24 (3), 875-888.

Zohary, D., Tchernov, E., and Kolska Horwitz, L., 1998. The role of unconscious selection in the domestication of sheep and goats. Journal of zoology, 245 (2), 129-135.

Figure 1: Schematic of various models of domestication and their effect on genetic diversity. Black and white dots represent alleles at an hypothetical locus in the genome of a domestic species. Ne is the effective population size: the number of breeding individuals in an idealised population (different from the census population size). Ne is directly related to genetic 
diversity. In these schematics, population size increases and decreases due to various events (e.g. bottlenecks) over time. This has an effect of overall genetic diversity. a) Basic model involving a founder effect and/or strong selection b) A model involving a mild domestication bottleneck and a strong bottleneck during breed formation - this illustrates that the genetic diversity of the modern population under this model and a model in Figure 1a are the same, yet the models are different c) this last panel represent the effect of gene-flow from a wild to a domestic population following a bottleneck. We can see in this schematic how genetic diversity can increase in the domestic population as a result of gene-flow. 
a)

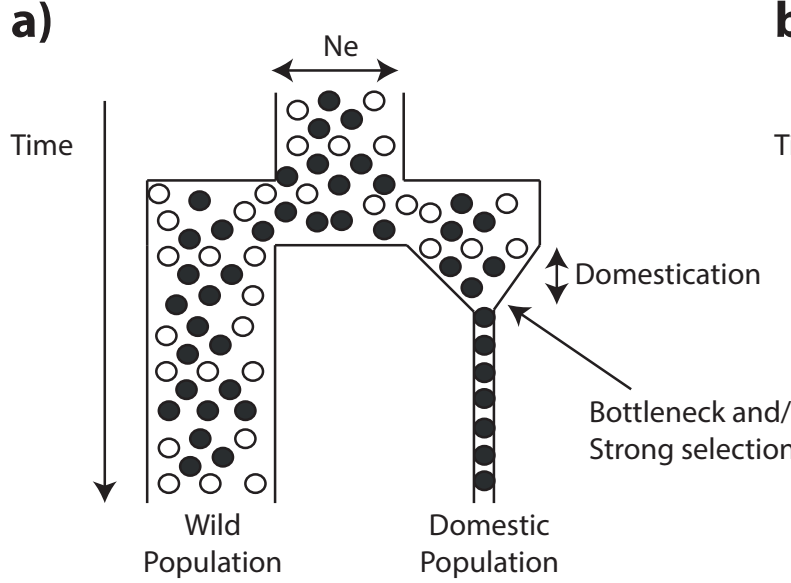

c)

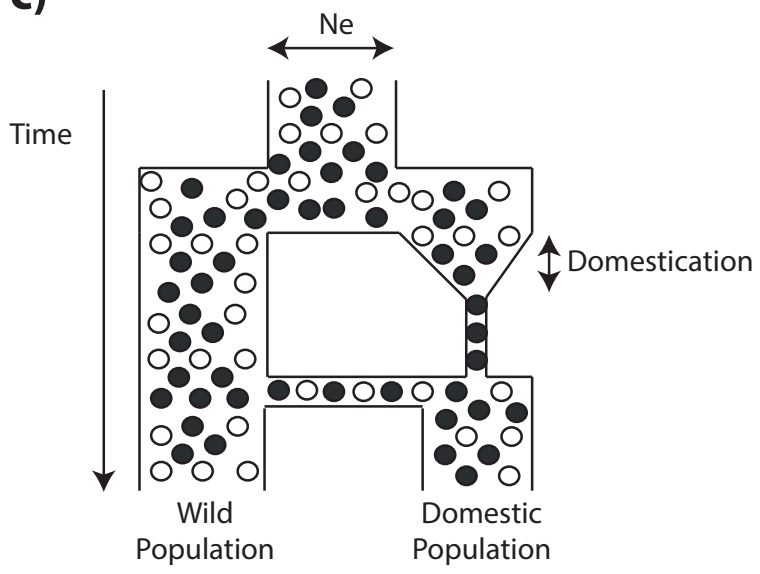

b)

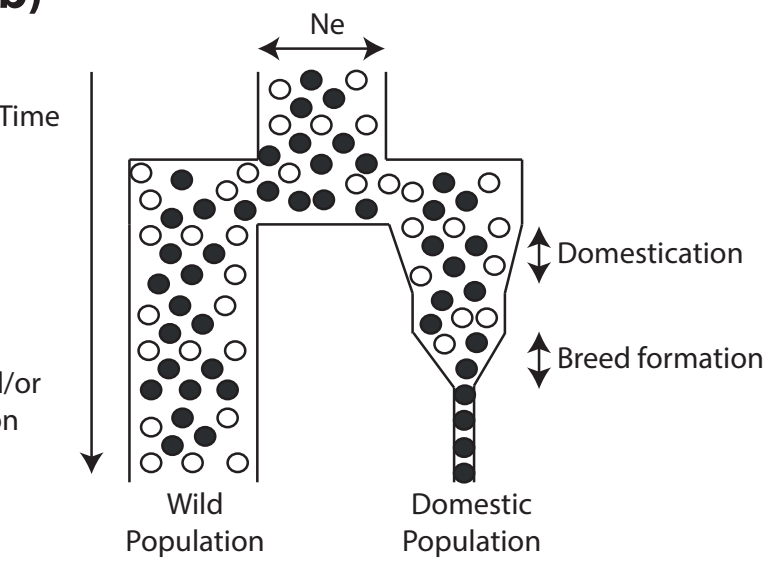

